\title{
Self-Regulated Learning and Prestasi Akademik Siswa Program Akselerasi Berdasarkan Jenis Kelamin
}

\author{
Siti Fatimah \\ Fakultas Psikologi, Universitas Muhammadiyah Malang \\ Email: geofatimah@umm.ac.id
}

\begin{abstract}
:
The study aimed to examine the correlation between self-regulated learning (SRL) and academic achievement; examine the correlation between cognitive, motivational, and behavioural regulations on academic achievement; and examine the difference of SRL level and academic achievement on male and female students of accelerated program in Senior High School of Malang. To analyse the data correlation of Pearson, multiple regression and t test were applied. The findings revealed that 1) there was significant positive correlation between SRL and academic achievement (r=.777);2) there was significant correlation between motivational and behavioural regulations and academic achievement; and 3) there was no significant difference between SRL level and academic achievement on male and female students on accelerated program.
\end{abstract}

Keyword: self regulated learning, academic achievement, accelarated program

Received February 11, 2019; Revised March 09, 2019; Accepted April 01, 2019

How to Cite: Fatimah, S. (2019). Self-Regulated Learning and Prestasi Akademik Siswa Program Akselerasi Berdasarkan Jenis Kelamin. JKI (Jurnal Konseling Indonesia), 4(2), 68-73.

This is an open access article distributed under the Creative Commons 4.0 Attribution License, which permits unrestricted use, distribution, and reproduction in any medium, provided the original work is properly cited. @2019 by author and Universitas Kanjuruhan Malang.

\section{PENDAHULUAN}

Program akselerasi merupakan program percepatan belajar bagi siswa yang memiliki potensi dan kemampuan di atas rata-rata dari masa belajar yang ditentukan dalam jangka waktu yang lebih cepat. Program ini diperuntukkan kepada siswa yang memiliki potensi kecerdasan dan bakat istimewa, dan memiliki karakteristik spesifik dari segi perkembangan kognitifnya. Dengan program ini diharapkan siswa dapat menyelesaikan pelajarannya lebih cepat. Percepatan akademik efektif bagi siswa yang memiliki kemampuan tinggi (Colangelo et al., 2010). Mereka membutuhkan lebih banyak kesempatan untuk mengembangkan bakatnya Hal berbeda diungkapkan oleh Boekaerts \& CornoLyn (2005) menjelaskan tentang faktor-faktor yang bisa mempengaruhi keberhasilan siswa dalam mencapai prestasi akademik yang maksimal. Faktor-faktor tersebut antara lain; kecerdasan, kepribadian, lingkungan sekolah, dan lingkungan rumah. Lebih jauh (Boekaerts \& CornoLyn, 2005) menjelaskan faktor lain yang bisa mempengaruhi siswa mencapai prestasi siswa yang maksimal adalah regulasi diri dalam belajar atau dikenal dengan self-regulated learning (SRL). Menurutnya, sekalipun siswa memiliki tingkat kecerdasan yang mewadai, kepribadian, dan lingkungan sekolah dan lingkungan rumah yang mendukung, akan tetapi kalau tidak didukung oleh kemampuan meregulasi diri dengan baik, maka siswa tersebut tetap tidak akan bisa mencapai prestasi yang optimal (Boekaerts \& CornoLyn, 2005). Sedangkan Schunk, (2001) menjelaskan bahwa siswa dikatakan dapat mereglasi diri dalam belajar apabila mereka mampu mengatur perilaku dan mengintegrasikan 
pengetahuannya secara sistematis. Secara umum sering kita lihat bahwa, tidak sedikit siswa yang tidak pernah memperhatikan regulasi yang dibuat sendiiri, mengontrol jalannya proses belajar mereka sendiri, termasuk mengingat informasi yang mereka peroleh. Permasalahan belajar yang terjadi sekarang ini tidak hanya terbatas pada kemampuan kognitif saja, melainkan pada pengaturan diri. Hal ini juga telah dijelaskan oleh Zimmerman (2002) yang mengemukakan bahwa regulasi diri dalam belajar penting bagi siswa disemua jenjang akademis.

Problem faktual di atas, sesuai dengan thoeritical problem yang diajukan Richert sebagaimana dikutip Stoeger \& Ziegler (2005) yang mengidentifikasi bahwa, sekitar 50\% siswa berbakat belum bisa mencapai prestasi akademik sesuai dengan potensinya. The National Commission on Exellence in Education (NCEE) yang juga memperkirakan bahwa, sekitar 50\% siswa berbakat tidak bisa mencapai tingkat prestasi akademik sesuai dengan kemampuannya (Clemons, 2008). Sternberg dan Clickenbeard melaporkan bahwa, anak berbakat lebih cepat dalam belajar, memproses informasi, lebih baik dalam menggunakan penalaran, dan memantau pemahaman mereka dengan lebih baik daripada anak yang tidak berbakat (Fasikhah, Suminarti \& Fatimah, 2013).

Stoeger \& Ziegler (2005) melaporkan bahwa penyebab belum tercapainya prestasi akademik secara optimal pada siswa berbakat karena faktor motivasional, kurang belajar, kebiasaan belajar dan rendahnya konsep diri, serta faktor yang berhubungan dengan kurangnya kemampuan meregulasi diri dalam belajar (self-regulated learning) pada strategi kognitif dan metakognitif dalam belajar. Siswa akan memperoleh prestasi akademik yang baik, apabila ia menyadari, memiliki tanggung jawab, dan mengerti strategi belajar yang efektif (Fasikhah, Suminarti \& Fatimah, 2013). Belajar bukan hanya dikontrol oleh aspek eksternal saja, tetapi juga dikontrol oleh aspek internal dan ia mampu merugulasi dirinya dalam belajar. Oleh karena itu, maka belajar harus dipahami sebagai sebuah proses aktif, konstruktif, signifikan, mediated, dan selfregulated (Montalvo, Torrano, Fermin; Carmen \& Torres, 2004). Self-regulated learning merupakan salah satu faktor yang berhubungan dengan prestasi akademik. Pintrich mendiskripsikan self-regulated learning sebagai kegiatan dimana siswa secara aktif, konstruktif, mampu menentukan tujuan belajar, merencanakan dan memonitor kegiatan belajarnya, mengatur dan mengontrol kognisi, motivasi, perilaku, serta lingkungan untuk mencapai tujuan yang telah ditetapkan dalam belajar (Wolters, Pintrich, \& Karabenick, 2005).

Beberapa hasil penelitian terdahulu tentang self-regulated learning mengindikasikan bahwa, SRL berkaitan erat dengan prestasi akademik. Hasil penelitian Pintrich \& Groot (1990) menemukan bahwa, SRL memiliki hubungan positif terhadap prestasi akademik. Lebih jauh mereka menjelaskan bahwa siswa yang memilki regulasi diri yang tinggi lebih banyak menggunakan strategi planning, organizational dan selfmonitoring daripada siswa yang memiliki regulasi diri rendah. Blair dan Razza menemukan perilaku meregulasi anak sejak usia dini dapat memprediksi prestasi belajarnya dibanding skor IQ-nya (Bodrova, Leong, \& Leong, 2018). Basuki, Heru (2005) menyimpulkan bahwa, siswa yang mampu memberdayakan strategi-atrategi SRL, utamanya strategi kognisi dan strategi metakognisi akan memperoleh prestasi akademik yang lebih tinggi dibanding dengan mereka yang kurang mampu memberdayakannya. Sungur Sava (2009) melaporkan bahwa lingkungan sekolah yang mendorong siswa meregulasi diri memiliki korelasi positif terhadap prestasi akademik. Stoeger \& Ziegler (2005) menemukan bahwa umumnya program intervensi SRL cocok untuk mengurangi underachievement dan pada akhirnya dapat meningkatkan prestasi akademik pada siswa Sekolah Dasar. SRL (mastery goal orientation) sebagai prediktor yang kuat terhadap self-efficacy dan memiliki pengaruh terhadap perolehan belajar. Gonzalez, Dowson, Brickman, \& Mcinerney (2003) menemukan bahwa ketujuh strategi regulasi motivasional secara bersama-sama memprediksi terhadap prestasi akademik. Cobb (2003) menemukan adanya korelasi yang positif antara aspek perilaku SRL dengan prestasi akademik. Chen (2002) menemukan hubungan yang signifikan antara strategi SRL dengan prestasi akademik. Begitu juga Ho \& Sui-Chu Ho (2004); Fritz \& Peklaj (2009); Dent, (2013); Basuki, Heru (2005) menemukan hubungan yang signifikan antara SRL dengan prestasi akademik Demikian juga hasil penelitian Zimmerman (Chen, 2002) juga menunjukkan bahwa, siswa perempuan lebih banyak menggunakan pengaturan diri dan lingkungan belajar, dengan memilih lingkungan belajar yang tenang dan relatif bebas dari gangguan secara visual dan suara yang dapat mengganggu kosentrasi.

Penelitian tentang self-regulated learning di Indonesia, saat ini masih belum banyak dilakukan dan informasinya juga masih sangat terbatas. Sehingga penelitian tentang "Self-Regulated Learning”, masih sangat penting untuk dilakukan. 


\section{METODE PENELITIAN}

Penelitian ini menggunakan rancanan penelitian kuantitatif korelasional. Subyek dalam penelitian ini adalah siswa program akselerasi yang berada di kelas X, di SMUN 01, SMUN 03, SMUN 04, dan SMUN 05 Malang, yang terdiri dari 78 siswa (27 laki-laki dan 51 perempuan).

Instrumen yang digunakan untuk mengukur SRL adalah skala belajar berdasarkan regulasi diri (SRL) yang dikembangkan dari MSLQ, dengan lima macam tingkat jawaban. Jumlah butir pertanyaan awal 103, dimana 26 butir berkaitan dengan regulasi kognitif, 36 butir berkaitan dengan regulasi motivasional dan 41 butir berkaitan dengan regulasi behavioral. Sedangkan untuk memperoleh data tentang prestasi akademik dan status jenis kelamin subyek, digunakan dokumentasi, yakni, kartu rapor subyek di kelas X pada semester genap.

Analisis data yang digunakan meliputi; uji prasyarat analisis dan uji hipotesis penelitian. Teknik analisis yang digunakan untuk menguji hipotesis dalam penelitian ini adalah teknik analisis statistik parametrik, yang meliputi: korelasi Pearson Product Moment); regresi ganda (multiple regression) dan uji t.

\section{HASIL}

Tabel 1. Hubungan antara self-regulated learning dan prestasi akademik pada siswa program akselerasi

\begin{tabular}{lll}
\hline Variabel & $\mathrm{r}$ & $\mathrm{p}$ \\
\hline Self-regulated learning & .777 & .000 \\
Prestasi akademik & .777 & .000 \\
\hline
\end{tabular}

Tabel 1 di atas menunjukkan bahwa hasil analisis dengan korelasi Pearson Product Moment, diperoleh nilai koefesien korelasi atau $\mathrm{r}=.777$ dengan $\mathrm{p}=.000$. Oleh karena $\mathrm{p}<.05$, maka H0 yang berbunyi ada hubungan yang signifikan antara self-regulated learning dan prestasi akademik pada siswa program akselerasi ditolak. Angka r=.777 tersebut, menunjukkan korelasi yang kuat, karena terletak antara .601 .800 .

Tabel 2. Hubungan Regulasi Kognitif, Rgulasi Motivasional, dan Regulasi Behavioral dengan Prestasi Akademik

\begin{tabular}{lllll}
\hline Variabel & Coefficients & SE & t & sig \\
\hline Constant & 58.722 & .332 & 25.182 & .000 \\
R. Kognitif & .023 & .019 & 1.177 & .243 \\
R. Motivasional & .133 & .017 & 7.625 & .000 \\
R. Behavioral & .073 & .17 & 4.187 & .000 \\
\hline
\end{tabular}

Tabel di atas menunjukkan bahwa bahwa, regulasi kognitif ditemukan tidak berhubungan secara signifikan dengan prestasi akademik, karena memiliki nilai $\mathrm{p}=.243$ atau $\mathrm{p}>.05$. Sedangkan regulasi motivasional dan regulasi behavioral ditemukan berhubungan secara signifikan dengan prestasi akademik, karena memiliki nilai $\mathrm{p}<.05$.

Tabel 3. Perbedaan Jenis Kelamin terhadap Regulasi Kognitif, Regulasi Motivasional, dan Regulasi

\begin{tabular}{llllll}
\multicolumn{7}{c}{ Behavioral } \\
\hline Variabel & F & Sig & Z & df & Sig (2-tailed) \\
\hline R. Kognitif & 8.546 & .005 & $-2,200$ & 76 & .031 \\
R. Motivasional & 0.037 & .848 & $-1,501$ & 76 & .138 \\
R. Behavioral & 0.003 & .945 & $-0,975$ & 76 & $-2,26144$ \\
\hline
\end{tabular}

Tabel 3 menunjukkan bahwa bahwa terdapat perbedaan regulasi kognitif secara signifikan antara siswa akselerasi laki-laki dan perempuan, karena diperoleh nilai $\mathrm{p}=0,031$, dimana tingkat regulasi kognitif siswa perempuan lebih tinggi dibandingkan siswa akselerasi laki-laki, dan tidak ada perbedaan tingkat regulasi motivasional dan behavioral yang signifikan antara siswa akselerasi laki-laki dan perempuan, karena nilai $\mathrm{p}$ $>0,05$. 
Tabel 4. Pengaruh Self-Regulated Learning dan Jenis Kelamin terhadap Prestasi Akademik

\begin{tabular}{llllll}
\hline Variabel & F & Sig & Z & df & Sig (2 tailed) \\
\hline SRL & 1.580 & .213 & $-1,933$ & 76 & .057 \\
Prestasi Akademik & .217 & .642 & $-0,733$ & 76 & .466 \\
\hline
\end{tabular}

Hasil pengujian pada table 4 di atas menunjkkan bahwa, variabel SRL diperoleh nilai $\mathrm{Z}=-1.933$ dengan $\mathrm{p}=.057$, dan pada variabel prestasi akademik diperoleh nilai $\mathrm{Z}=-.733$ dengan $\mathrm{p}=.466$. Oleh karena $\mathrm{p}>.05$, maka H0 diterima, sehingga terbukti tidak terdapat perbedaan secara signifikan tingkat SRL dan prestasi akademik pada siswa program akselerasi laki-laki dan perempuan pada taraf kepercayaan $95 \%$. hipotesis yang berbunyi tidak terdapat perbedaan tingkat SRL dan prestasi akademik yang signifikan pada siswa program akselerasi laki-laki dan perempuan diterima. Berdasarkan hasil analisis uji t diperoleh nilai $\mathrm{p}>.05$ pada kedua variabel baik pada SRL maupun prestasi akademik.

\section{PEMBAHASAN}

Temuan ini mendukung hasil penelitian sebelumnya, yang dilakukan oleh Basuki, Heru (2005) yang menemukan bahwa, SRL berkontribusi terhadap prestasi akademik, baik secara langsung maupun tidak langsung; serta hasil penelitian (Freeman, 2004) menunjukkan bahwa, siswa berbakat di kelas akselerasi yang berprestasi, ditemukan lebih sering menggunakan strategi SRL dan lebih efektif, mampu menstransfer ketrampilan SRL pada tugas-tugas baru, dan lebih banyak menunjukkan autonomi dalam belajar. Hasil temuan kedua, didukung hasil penelitian sebelumnya yang dilakukan oleh, (Gonzalez et al., 2003)yang menemukan bahwa, regulasi motivasional akademik (self-regulating academic motivasional) berhubungan secara signifikan terhadap prestasi akademik, dan (Cobb, 2003) yang menemukan bahwa, ada hubungan yang signifikan antara self-regulated learning behavior dengan prestasi akademik. Sedangkan tidak ditemukan hubungan yang signifikan antara regulasi kognitif dengan prstasi akademik pada siswa akselerasi tersebut, mungkin dikarenakan siswa akselerasi memiliki karakteristik yang unggul dalam pemrosesan informasi serta kemampuan belajar lebih cepat, sebagaimana Ellen Winner (Freeman, 2004), mendiskripsikan tiga kriteria yang menjadi ciri anak berbakat yaitu; dewasa lebih dini (precocity), belajar menuruti kemauan sendiri dan memiliki semangat yang tinggi, serta unggul dalam pemrosesan informasi, serta menggunakan penalaran dan pemantauan yang lebih baik daripada anak yang tidak berbakat. Oleh karena itu, maka aspek regulasi kognitif ditemukan tidak berhubungan secara signifikan dengan prestasi akademik. Hasil penelitian Pintrich \& Groot (1990) menemukan bahwa, SRL memiliki korelasi yang signifikan terhadap prestasi akademik, siswa yang memiliki regulasi diri yang tinggi lebih banyak menggunakan strategi planning, organizational dan self-monitoring daripada siswa yang memiliki regulasi diri rendah

Hasil penelitian ini didukung penelitian Zimmerman (2002) yang mengemukakan bahwa regulasi diri dalam belajar penting bagi siswa disemua jenjang akademis. Temuan Zimmerman sebelumnya yang menemukan bahwa, siswa perempuan memiliki kecenderungan umum yang lebih besar dalam penggunaan strategi self-regulated learning daripada siswa laki-laki. Secara spesifik siswa perempuan dilaporkan lebih banyak melakukan pencatatan (keeping record) dan pemantauan (monitoring) serta melakukan penyusunan dan perencanaan tujuan (goal setting dan planning). Dimana kegiatan tersebut, menurut Wolters et al. (2005) masuk dalam ruang lingkup aspek regulasi kognitif.

Secara kontras, hasil penelitian ini tidak ditemukanya perbedaan tingkat SRL dan prestasi akademik pada subyek laki-laki dan perempuan, dikarenakan instrumen SRL yang digunakan dalam penelitian ini berlaku secara umum dan tidak fokus pada bidang studi tertentu yang ada dominasi gender. Demikian juga prestasi akademik yang digunakan dalam penelitian ini adalah nilai rata-rata dari keseluruhan bidang studi (CGPA), dan bukan prestasi akademik dalam bidang studi tertentu yang ada dominasi gender seperti bidang studi bahasa, matematika ataupun hard science. Hasil penelitian ini didukung oleh hasil penelitian sebelumnya yang dilakukan oleh (Naderi, Abdullah, Hamid, \& Kumar, 2009) dengan menggunakan nilai rata-rata keseluruhan bidang studi (CGPA) juga menemukan bahwa, tidak ada perbedaan prestasi (CGPA) antara siswa laki-laki dan perempuan. Demikian juga hasil penelitian Arnot, Ruduck dan Gray (Freeman, 2004) di Britain juga menemukan, tidak ada perbedaan prestasi akademik yang signifikan antara siswa berbakat laki-laki dan perempuan, pada seluruh area bidang studi dan pada seluruh usia sekolah. 


\section{SIMPULAN DAN SARAN}

Berdasarkan hasil penelitian dan pembahasan dapat disimpulkan bahwa 1) ada hubungan yang signifikan antara SRL dengan prestasi akademik siswa program akselerasi; 2) tidak ada hubungan yang signifikan antara regulasi kognitif dengan prestasi akademik, dan ada hubungan yang signifikan antara regulasi motivasional dan regulasi behavioral dengan prestasi akademik pada siswa program akselerasi; dan 3) tidak terdapat perbedaan tingkat SRL dan prestasi akademik yang signifikan antara siswa program akselerasi laki-laki dan perempuan.

Berdasarkan hasil penelitian, disarankan kepada (1) pengelola program akselerasi untuk memfasilitasi kepada para guru yang mengajar siswa program akselerasi untuk mengikuti in-service training tentang SRL, sehingga para guru memiliki pengetahuan, ketrampilan, dan kompetensi tentang regulasi diri yang baik, sehingga dapat mengembangkan SRL siswa dalam proses belajar mengajar, karena berdasarkan hasil penelitian ditemukan hubungan positif yang kuat antara SRL dan prestasi akademik pada siswa program akselerasi. 2) Para guru khususnya guru program akselerasi untuk menciptakan kondisi lingkungan belajar yang dapat menstimulasi perkembangan SRL siswa dan dapat mendesain tugas-tugas belajar yang dapat mendorong siswa untuk melakukan SRL, baik secara kognitif, motivasional maupun behavioural. 3) Siswa, khususnya siswa akselerasi untuk meningkatkan penggunaan strategi SRL dalam proses belajar, terutama pada aspek regulasi motivasional dan behavioural. 4) Peneliti selanjutnya untuk menambahkan variabelvariabel lain dalam meneliti SRL, menggunakan subyek laki-laki dan perempuan yang seimbang, menyempurnakan instrumen dan menguji kembali validitas dan reliabilitasnya serta mengkombinasikan instrumen tersebut dengan teacher judgment, agar hasil penelitian lebih akurat, dan juga menggunakan desain penelitian eksperimental maupun kualitatif.

\section{DAFTAR RUJUKAN}

Basuki, Heru, A. M. (2005). Pengujian Kontribusi Belajar yang Bermakna Ppada Kreatifitas, Self Regulated Learning, dan Prestasi Akademik (Studi Kasus pada Siswa Sekolah Menengah di Jakarta). In Proceeding, Seminar Nasional PESAT (pp. 23-24).

Bodrova, E., Leong, D. J., \& Leong, D. J. (2018). Developing Self-Regulatio in Kindergarten Can We Keep All the Crickets in the, 63(2), 56-58.

Boekaerts, M., \& CornoLyn. (2005). Self-Regulation in the Classroom: A Perspective on Assessment and Intervention. Applied Psychology: An International Review, 54(2), 239-244.

Chen, C. S. (2002). Self-Regulated Learning Strategies and Achievement in an Introduction to Information Systems Course. Information Technology, Learning, and Performance Journal, 20(1), 11-25.

Clemons, L. T. (2008). Underachieving Gifted Students: A Social Cognitive Mode (April). The National Research Center on the Gifted and Talented University of Connecticut. https://doi.org/10.1515/JURA.2009.579

Colangelo, N., Assouline, S. G., Marron, M. A., Castellano, J. A., Clinkenbeard, P. R., Rogers, K., ... Smith, D. (2010). Guidelines for Developing an Academic Acceleration Policy. National Work Group on Acceleration. Journal of Advanced Academics, 21(2), 180-203. https://doi.org/10.1177/1932202X1002100202

Dent, A. L. (2013). The Relation Between Self-Regulation and Academic Achievement: A Meta-Analysis Exploring Variation in the Way Constructs are Labeled, Defined, and Measured. Disertation, 225. https://doi.org/10.1073/pnas.0703993104

Fasikhah, Suminarti, S., \& Fatimah, S. (2013). SESelf Regulated Learning (SRL) dalam Meningkatkan Prestasi Akademik pada Mahasiswa, 01(01), 145-155.

Freeman, J. (2004). Teaching the gifted and talented. Education Today, 54, 17-21.

Fritz, B. S., \& Peklaj, C. (2009). Self-regulated Processes as Predictors of Students' Achievement in Music Theory in Slovenian Elementary Music Schools Samoregulativni procesi kot prediktorji uspešnosti učencev glasbene šole pri nauku o glasbi, 18, 5-18.

Gonzalez, S., Dowson, M., Brickman, S., \& Mcinerney, D. M. (2003). GON05371 Self-Regulation of Academic Motivation: Advances in Structure and Measurement Sonia Gonzalez, Martin Dowson, Stephanie Brickman and Dennis M. McInerney. Self.

Ho, E. S.-C., \& Sui-Chu Ho, E. (2004). Self-Regulated Learning and Academic Achievement of Hong Kong Secondary School Students. Education Journal, 32(2), 87-107. Retrieved from http://login.ezproxy.lib.umn.edu/login?url=http://search.ebscohost.com/login.aspx?direct=true\&A

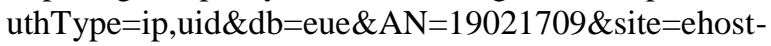


live\%5Cnhttp://login.ezproxy.lib.umn.edu/login?url=http://search.ebscohost.com/login.aspx?direc $\mathrm{t}=$ true \&AuthType=ip, $\mathrm{u}$

Jr. Cobb, R. (2003). The relationship between self-regulated learning behaviors and academic performance in web-based courses. Disertation, 54(2), 1-124. Retrieved from http://www.mendeley.com/research/no-title-avail/

Montalvo, Torrano, Fermin; Carmen, M., \& Torres, G. (2004). Self-Regulated Learning : Current and Future Directions. Electronic Journal of Research in Educational Psychology, 2(1), 1-34.

Naderi, H., Abdullah, R., Hamid, T. A., \& Kumar, J. S. V. (2009). Intelligence , Creativity and Gender as Predictors of Academic Achievement among Undergraduate Students. Intelligence, Creativity and Gender as Predictors of Academic Achievement among Undergraduate Students, 5(3), 8-19.

Pintrich, P. R., \& Groot, E. V. De. (1990). Motivational and Self-Regulated Learning Components of Classroom. Journal of Educational Psychology, 82(1), 33-40.

Schunk, H. D. (2001). Self-regulation through Goal Setting. ERIC Digest, (December).

Stoeger, H., \& Ziegler, A. (2005). Evaluation of an elementary classroom self-regulated learning program for gifted mathematics underachievers. International Education Journal, 6(2), 261-271.

Sungur Sava, S. (2009). The Role of Classroom Environment Perceptions in Self-Regulated Learning and Science Achievement. Elementary Education Online, 8(3), 883-900. Retrieved from http://ilkogretim-online.org.tr

Wolters, A. C., Pintrich, R. P., \& Karabenick, A. S. (2005). Assesing Academic Self-Regulated Learning. What Do Children Need to Flourish? (Vol. 3). https://doi.org/10.1007/0-387-23823-9

Zimmerman, B. (2002). Becoming a self regulated learner(TIP2002).pdf. Theory and Practice, 41(2). 